\title{
Original research article Relationship between midpalatal suture maturation and age and maturation of cervical vertebrae: radiographic evaluation
}

\author{
Hande Gorucu-Coskuner, ${ }^{*}$ Ezgi Atik, Tülin Taner \\ Department of Orthodontics, Faculty of Dentistry, \\ Hacettepe University, Ankara, Turkey
}

\begin{abstract}
OвJECTIVE: To evaluate the stages of midpalatal suture (MPS) maturation in patients older than 15 years, and to determine the correlation between the stage of MPS maturation and age and cervical vertebral maturation (CVM).

Materials And Method: Cone-beam computed tomography (CBCT) scans of 50 patients (29 female and 21 male; mean age, $19.79 \pm 4.09$ years) were evaluated. Good quality CВCT images from 15-30-year-old patients for evaluation of impacted canines or determination of orthognathic surgery were selected. The СВСТ images were evaluated at two different time intervals for determination of the stages of MPS and CVM. The stages of MPS maturation were classified as A, B, C, D, or E using the axial sections by using a method validated previously. The stages of CVM were classified using sagittal sections of the CBCT images. Intra-examiner agreement was assessed using the Kappa test. The correlations between MPS maturation and chronological age and CVM were assessed using Spearman's rank correlation analysis.
\end{abstract}

RESULTS: The Kappa coefficients for intra-examiner agreement were 0.837 and 0.865 for classification of the stages of MPS maturation and CVM, respectively. No significant correlation was observed between chronological age and maturation of MPS $(r=0.212, p=$ 0.139) and between the stages of CVM and maturation of MPS $(r=0.030, p=0.839)$.

CONCLUSION: The limitation of our study was a small sample size, and, on the basis of our results, neither CVM nor chronological age could be used as a convenient tool to determine the stage of MPS maturation in 15-30-year-old patients.
Received: March 16, 2018; Accepted: July 13, 2018

*Corresponding author: Dr. Hande Gorucu-Coskuner, Department of

Orthodontics, Faculty of Dentistry, Hacettepe University, Sıhhıye, 06100 ,

Ankara, Turkey;

E-mail: hande.gorucu@ hotmail.com
KEYWORDS: Cone-beam computed tomography; growth and development; orthodontics

Citation: Gorucu-Coskuner H, Atik E, Taner T. Relationship between midpalatal suture maturation and age and maturation of cervical vertebrae: radiographic evaluation. Acta Odontol Turc 2018;35(3):69-74

EdıToR: Emine Kaygısız, Gazi University, Ankara, Turkey

Copyright: (c) 2018 Gorucu-Coskuner et al. This work is licensed under a Creative Commons Attribution License. Unrestricted use, distribution and reproduction in any medium is permitted provided the original author and source are credited.

FundING: None declared.

CONFLICT OF INTEREST: The authors declare no conflict of interest related to this study.

\section{INTRODUCTION}

The most effective orthodontic treatment for increasing the maxillary transverse width is rapid maxillary expansion (RME). ${ }^{1}$ The maxilla can be expanded at a skeletal level using this method by opening the midpalatal suture (MPS). ${ }^{2}$ With the closure of the craniofacial sutures and an increase in density of the MPS, RME cannot be performed using the conventional method ${ }^{3}$ and surgically assisted techniques are required to provide skeletal expansion. . $^{4}$ In addition to being invasive and expensive, surgically assisted techniques are associated with surgical risks. ${ }^{6,7}$

Various methods have been proposed to evaluate the stage of MPS maturation using 3-dimensional images to predict the need for surgical treatment to support RME.,9 Recently, Grünheid et al. ${ }^{8}$ suggested that the MPS density ratio may be a useful clinical predictor of the skeletal response to RME and aid in clinical decisions about the need of surgical assistance. Angelieri et al. ${ }^{9}$ suggested a method of classification for individual assessment before RME by using cone-beam computed tomography (CBCT). Both methods are designed to avoid the side effects of RME failure or unnecessary surgical assistance for RME for late adolescents or young adults. However, both methods require $\mathrm{CBCT}$ 
scans of the patients, and thus involve additional exposure to radiation.

Prediction of the stage of MPS maturation by determining the chronological age or cervical vertebral maturation (CVM) stage ${ }^{10}$ instead of 3-dimensional examination of the midpalatal suture ${ }^{11}$ may prevent the patient from additional exposure to radiation. Thus, this study aimed to assess the stage of maturation of the MPS in 15-30-year-old patients by using CBCT, and to determine the association between the stage of MPS maturation with chronological age and CVM.

\section{Materials and Method}

Ethical approval for this study was granted by the Hacettepe University Ethical Committee (institutional review board number: GO 17/968-38).

CBCT images of 50 patients (29 female and 21 male) were randomly selected from the digital archives of Hacettepe University, Faculty of Dentistry, Department of Orthodontics. The inclusion criteria were as follows: (1) good quality CBCT images taken to evaluate impacted canines or determine the need for orthognathic surgery previously and (2) patients between 15-30 years old. The exclusion criteria were as follows: (1) patients with previous orthodontic or orthopedic treatment and (2) patients with cleft lip palate or any craniofacial syndrome. All CBCT scans were acquired using the iCAT Cone Beam 3D Imaging System (Imaging Sciences International Inc., Hatfield, PA, USA) at maximum intercuspation when the subjects were in an upright sitting position with the Frankfurt horizontal plane parallel to the floor. The settings for the CBCT machine were as follows: $23 \times 17 \mathrm{~cm}$ field of view (voxel size, $0.30 \mathrm{~mm}$ ), $120-\mathrm{kVp}$ tube voltage, tube current of $2 \mathrm{~mA}$, and 17.8 $\mathrm{s}$ scan time. Data were exported in the DICOM format. Dolphin 3D program (version 11.8, Dolphin Imaging \& Management Solutions, Chatsworth, CA, USA) was used to display the images.

Before evaluating the CBCT images, two orthodontists were trained to classify the stages of MPS maturation and CVM by using the methods described by Angelieri et al. ${ }^{9}$ and Bacetti et al. ${ }^{12}$ The calibration exercise was performed using CBCT images of 20 subjects at the beginning of the study.

Initially, all selected patients were listed and identified by numbers both in the imaging software and tables used for assessments. All variables assessed for the research were registered at different tables to prevent bias. Two calibrated orthodontists made the observational assessments of the stages of MPS maturation and CVM. For the constitution of the images for MPS assessment, the cursor of the image analysis software was aligned to the MPS level, at both coronal and axial views. In the sagittal section, the horizontal reference line was aligned with the median region of the palate (Figure 1). The classification of the MPS maturation stage was performed at the axial section as A, B, C, D, or $\mathrm{E}$ by using a method described by Angelieri et al. ${ }^{9}$ Stage A represents straight high-density sutural line, with no or little interdigitation; stage B indicates scalloped appearance of the high-density sutural line; stage $\mathrm{C}$ indicates 2 parallel, scalloped, high-density lines that were close to each other, separated in some areas by small low-density spaces; stage $D$ indicates fusion completed in the palatine bone, with no evidence of a suture; and stage $\mathrm{E}$ indicates fusion anteriorly in the maxilla. In the case of a curved palate, 2 images were created for determining the stage of MPS maturation, one image from the front and one image from the rear part of palate. Images of MPS stages B, C, D, and E from the axial views evaluated in our study are shown in Figure 2.

Two blinded examiners (H.G-C. and E.A.) worked together for both creation of the best axial slice for evaluation and for classification of MPS maturation stages. This was considered as the main evaluation. After 15 days, the images of all 50 subjects were created and evaluated by the same two observers again to establish reliability. When the two classifications were different, a third assessment was performed to reach consensus.

Lateral cephalometric radiographs were created for classification of CVM stage. It was classified as CS1, CS2, CS3, CS4, CS5, or CS6 according to the modified method of Bacetti et al. ${ }^{12}$ Finally, the chronological ages of the subjects at the time the CВCT image was taken were enlisted from the database of the faculty.

\section{Statistical analysis}

SPSS (Version 21.0, SPSS Inc., Chicago, IL, USA) was used for statistical analysis. Intra-examiner agreement was assessed using the kappa test. The agreement was defined by using the scale of Landis and Koch. ${ }^{13}$ The distribution of the maturation stages by age and sex was presented as absolute and percentage fre-

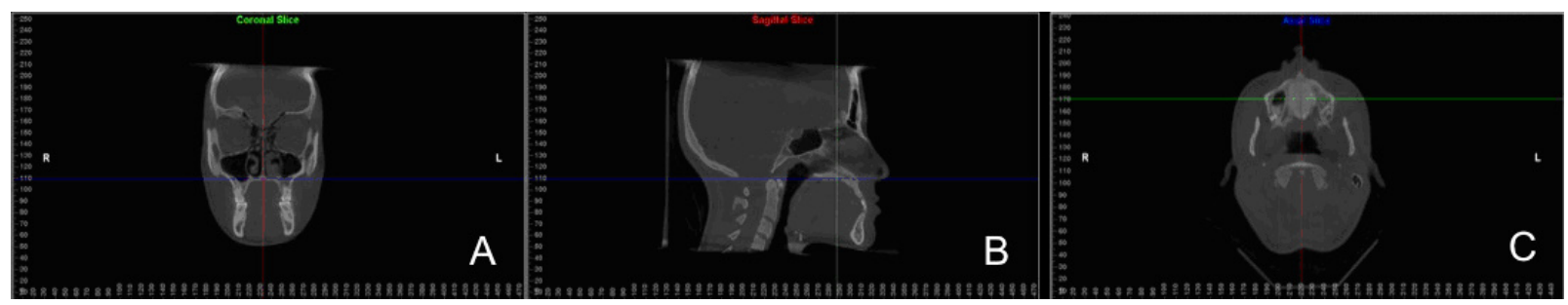

Figure 1. The reference lines used for the constitution of the images at $(A)$ coronal, $(B)$ sagittal, and $(C)$ axial views 


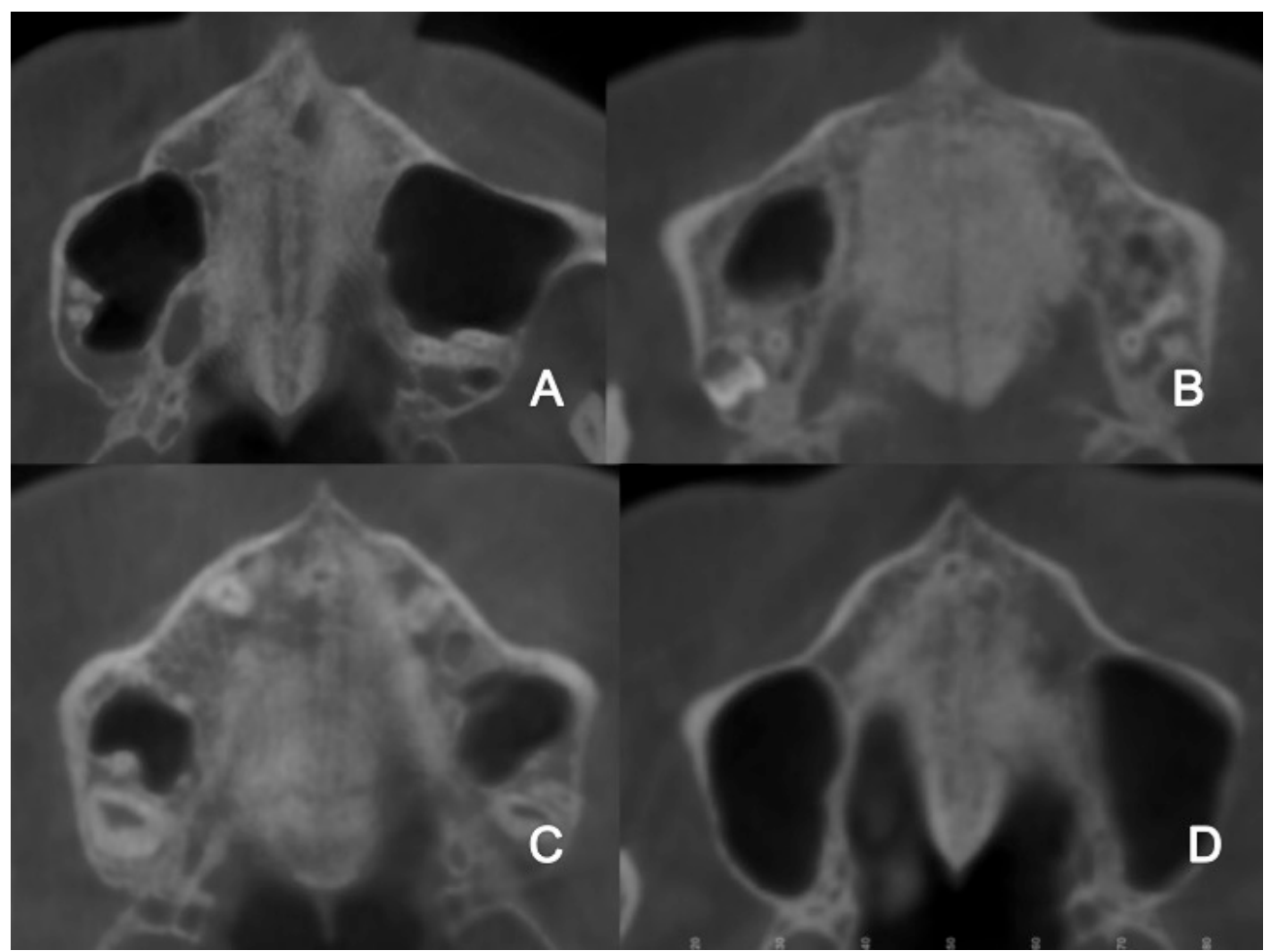

Figure 2. Examples of the midpalatal suture (MPS); (A) Stage B, (B) Stage $C,(C)$ Stage D, and (D) Stage $E$

quencies. The distribution of the MPS maturation stages by chronological age and sex was presented as median, minimum, and maximum values. The correlations between MPS maturation and chronological age and CVM were assessed with Spearman's rank correlation analysis. Statistical significance was set at $p<0.05$.

\section{Results}

The Kappa coefficients for intra-examiner agreement were 0.837 and 0.865 for classification of stages of MPS maturation and CVM, respectively. Both values represent almost perfect intra-examiner agreement according to Landis and Koch. ${ }^{13}$

The distribution of the stage of maturation by age and sex is presented in Table 1. Between 15 and 18 years age, the most common stage of MPS maturation was $C$ for female and stages $C$ and $D$ for male. Between 19 and 24 years age, the most common stages of MPS maturation were $C$ and $E$ for female and $D$ for male. Between 25 and 30 years old, the MPS maturation stages were mostly $D$ and $E$ in female, and $B, C$, and $E$ in male.

The distribution of the MPS maturation stages by chronological age and sex is shown in Table 2. Distributions of the MPS maturation stages according to the CVM stages are shown in Table 3. No significant correlation was observed between the chronological age and the stage of MPS maturation $(r=0.212, p=0.139$; Table 2). Further, no significant correlation was observed between the CVM and MPS maturation stages $(r=0.030, p=0.839$; Table 3$)$.

Table 1. Distribution of the stages of maturation by age and sex

\begin{tabular}{|c|c|c|c|c|c|c|c|c|c|c|c|}
\hline \multirow{3}{*}{ Chronological age (years) } & & \multicolumn{10}{|c|}{ Midpalatal suture maturation stage } \\
\hline & \multirow[b]{2}{*}{ Gender } & \multicolumn{2}{|l|}{ B } & \multicolumn{2}{|l|}{ C } & \multicolumn{2}{|l|}{ D } & \multicolumn{2}{|l|}{$\mathbf{E}$} & \multicolumn{2}{|c|}{ Total } \\
\hline & & $\mathbf{n}$ & $\%$ & $\mathbf{n}$ & $\%$ & $\mathbf{n}$ & $\%$ & $\mathbf{n}$ & $\%$ & $\mathbf{n}$ & $\%$ \\
\hline \multirow[t]{2}{*}{$15-18$} & Female & 4 & 25 & 7 & 43.8 & 3 & 18.8 & 2 & 12.4 & 16 & 100 \\
\hline & Male & 1 & 14.2 & 3 & 42.9 & 3 & 42.9 & 0 & 0 & 7 & 100 \\
\hline \multirow[t]{2}{*}{ 19-24 } & Female & 1 & 12.5 & 3 & 37.5 & 1 & 12.5 & 3 & 37.5 & 8 & 100 \\
\hline & Male & 2 & 18.2 & 2 & 18.2 & 4 & 36.3 & 3 & 27.3 & 11 & 100 \\
\hline \multirow[t]{2}{*}{$25-30$} & Female & 0 & 0 & 1 & 20 & 2 & 40 & 2 & 40 & 5 & 100 \\
\hline & Male & 1 & 33.3 & 1 & 33.3 & 0 & 0 & 1 & 33.3 & 3 & 100 \\
\hline
\end{tabular}


Table 2. Distribution of the stages of midpalatal suture maturation by chronological age and sex and correlations between the stage of midpalatal suture maturation and chronological age

\begin{tabular}{|c|c|c|c|c|c|}
\hline \multirow{2}{*}{$\begin{array}{l}\text { Midpalatal suture maturation stages } \\
\text { Females }\end{array}$} & \multicolumn{5}{|c|}{ Chronological age } \\
\hline & Median & Minimum & Maximum & $\mathbf{R}^{*}$ & p \\
\hline Stage $B(n=5)$ & 16.66 & 15.78 & 20.70 & 0.212 & 0.139 \\
\hline Stage $C(n=11)$ & 16.68 & 15.04 & 30.39 & & \\
\hline Stage $D(n=6)$ & 20.43 & 16.65 & 29.64 & & \\
\hline Stage $E(n=7)$ & 20.04 & 16.77 & 26.98 & & \\
\hline Total $(n=29)$ & 17.57 & 15.04 & 30.39 & & \\
\hline \multicolumn{6}{|l|}{ Males } \\
\hline Stage $B(n=4)$ & 21.81 & 17.63 & 28.63 & & \\
\hline Stage $C(n=6)$ & 17.70 & 15.04 & 24.30 & & \\
\hline Stage $D(n=7)$ & 18.77 & 15.05 & 20.81 & & \\
\hline Stage $E(n=4)$ & 21.48 & 19.39 & 25.08 & & \\
\hline Total $(n=21)$ & 19.72 & 15.04 & 28.63 & & \\
\hline
\end{tabular}

*Spearman's rank correlation analysis; values are presented as $R$ (correlation coefficient) and $p$ (significance value)

\section{Discussion}

Maxillary expansion by opening the MPS is thought to become progressively difficult as the patient grows old; ${ }^{3}$ but, in the case of some patients, sutures can be separated without surgery even in patients older than 18 years. ${ }^{14,15}$ Substantial variability has been reported in the rate and extent of the fusion of the midpalatal suture in relation to chronological age. ${ }^{16,17}$ Skeletal maturation varies among different age groups, and chronological age is not a reliable indicator in determining the amount of bone development. ${ }^{18}$ Thus, the use of radiographs for the estimation of the skeletal age has been considered. The conventional methods for determining the skeletal age are evaluation of hand-wrist radiographs ${ }^{19}$ and cervical vertebrae. ${ }^{20}$ Cervical vertebrae are visible on lateral cephalometric radiographs, which are routinely acquired in patients undergoing orthodontic treatments; therefore, determining the skeletal age by determining the CVM decreases the exposure of the patient to radiation. ${ }^{12,18,20,21}$

In young adults, usually an occlusal radiograph is taken, and the sutural space is evaluated to determine the need of surgical assistance to RME. ${ }^{15,22}$ However, evaluation of the MPS in occlusal radiographs may be difficult because of the anatomical superimpositions. ${ }^{22}$ To overcome this issue, Angelieri et al. ${ }^{9}$ recommended classification of MPS maturation using on 3-dimensional CBCT images.

Angelieri et al. ${ }^{9}$ suggested that their method of classification of MPS maturation might provide reliable parameters to arrive at the clinical decision of conventional or surgically assisted RME for adolescent and young adult patients by diagnosing the overall anteroposterior characteristics of the MPS. MPS maturation was classified in 5 stages by evaluating the morphology and degree of fusion of the MPS. This study aimed to assess the stage of MPS maturation in 15-30-year-old patients by using the abovementioned method, and to determine the association of this stage with chronological age and CVM stage.

Among 15-18-year-old patients, MPS maturation stage $\mathrm{C}$ was observed in $43.8 \%$ of female, and $85.8 \%$ male showed stages $\mathrm{C}$ and $\mathrm{D}$, with equal distribution. Among 19-24-year-old patients, $37.5 \%$ of the female were at stage $\mathrm{C}$ and $37.5 \%$ at stage $\mathrm{E}$. Most of the male $(36.3 \%)$ in that age range were at stage D. Most of the 25-30-year-old patients showed stages $D$ and $E$ in female, and an equal number of male showed stages $B$, $\mathrm{C}$, and $\mathrm{E}$. Angelieri et al. ${ }^{23}$ evaluated the CBCT images of 78 adults and reported that $12 \%$ of the adults were at MPS maturation stages B and C. Our results showed an irregular distribution of the stages of MPS maturation, especially in male between 25 and 30 years of age. These results may be attributed to the low sample size of our study.

Evaluation of the distribution of the MPS maturation stages by chronological age and sex showed the median chronological ages of female in MPS maturation stages B, C, D, and E were 16.66, 16.68, 20.43, and 20.05 years, respectively. These results indicate that the stage of MPS maturation increases with an increase in the age of the subject. However, the median age for stage $B$ was 21.81 years, which was higher than the median ages of stages $C, D$, and $E$ for male. We observed no significant correlation between the chronological age and MPS maturation stage of the subjects. Our findings are consistent with those of Korbmacher et $a l .^{16}$ who showed that the extent of interdigitation of 
Table 3. Distribution of the stages of midpalatal suture maturation according to the cervical vertebral maturation stages and correlations between midpalatal suture and cervical vertebral maturation

\begin{tabular}{|c|c|c|c|c|c|c|c|}
\hline \multirow[b]{2}{*}{ Cervical vertebral maturation stages } & \multicolumn{4}{|c|}{ Midpalatal suture maturation stages } & \multirow[b]{2}{*}{ Total } & \multirow[b]{2}{*}{$\mathbf{R}^{*}$} & \multirow[b]{2}{*}{ p } \\
\hline & Stage B & Stage C & Stage D & Stage $\mathbf{E}$ & & & \\
\hline $\operatorname{cs3}$ & 2 & 3 & 1 & 0 & 6 & 0.030 & 0.839 \\
\hline $\operatorname{cs} 4$ & 3 & 12 & 8 & 8 & 31 & & \\
\hline CS5 & 3 & 2 & 2 & 1 & 8 & & \\
\hline cs6 & 1 & 0 & 2 & 2 & 5 & & \\
\hline Total & 9 & 17 & 13 & 11 & 50 & & \\
\hline
\end{tabular}

${ }^{*}$ Spearman's rank correlation analysis; values are presented as $R$ (correlation coefficient) and $p$ (significance value)

the MPS was independent of chronological age. Similarly, Angelieri et al. ${ }^{23}$ and Haghanifar et al. ${ }^{24}$ showed that chronological age is not a statistically significant predictor of the MPS maturation stage.

Evaluation of the distribution of the stages of MPS maturation according to the CVM stages showed that most of the subjects were at the CS4 period. At CS3 and CS4 periods, the most commonly observed stage of MPS maturation was stage C. At CS3 stage, none of the subjects were at MPS maturation stage E, but at the CS6 stage, one of the subjects was at MPS maturation stage B. Evaluation of the overall records showed no significant correlation between the stages of MPS maturation and CVM. Our results are different from those of Angelieri et al. ${ }^{10}$ who suggested that most stages of CVM could be used for the diagnosis of the stages of maturation of the MPS. In addition, their results showed that an assessment of the stage of MPS maturation by using CBCT may be necessary in patients in the postpubertal period. The patients in our study were in the pubertal and post-pubertal period, according to the CVM stage. Our results show that chronological age in adults is not an important predictor for suture maturation. Although the rate of sutural closure increases with age, chronological age cannot be regarded as the single factor that determines suture maturation. Most subjects showed MPS maturation stage C at the CS4 cervical maturation stage. Thus, in the post-pubertal period, MPS was not fused in most of the patients and this situation can indicate that even in the post-pubertal period, conventional RME procedure might have a good prognosis.

One of the limitations of the our study was the sample size. We do not routinely perform CBCT imaging in our clinic because of exposure to excessive doses of radiation; thus, we selected only 50 subjects who met the inclusion criteria. Our results showed that skeletal age or the obliteration index may not be useful for differential diagnosis when determining the application of conservative RME for an orthopedic expansion. ${ }^{16}$ Grünheid et al. ${ }^{8}$ suggested that the MPS density ratio was a more useful predictor than chronologic age, CVM, or
MPS maturation stage, which had no significant correlations to the amount of long-term skeletal expansion. Furthermore, previous studies showed that in addition to MPS, circummaxillary sutures such as the zygomaticomaxillary, zygomaticotemporal, and pterygopalatine sutures represent the primary anatomical resistance to surgically assisted RME. ${ }^{25,26}$ Our study only evaluates the association between the stage of MPS maturation with age and cervical vertebral maturity and does not provide any information about the clinical effectiveness of this method in determining the need of surgical assistance for RME. Extensive clinical studies should be designed to analyze the clinical effectiveness of determination of the stage of MPS maturation on predicting the need of surgical assistance for RME.

\section{Conclusion}

The MPS maturation stages vary widely in terms of chronological age and CVM. The limitation of our study was a small sample size, and our results showed that neither CVM nor chronological age could be a convenient tool for determining the stage of MPS maturation in 15-30-year-old patients.

\section{References}

1. Haas AJ. The Treatment of Maxillary Deficiency by Opening the Midpalatal Suture. Angle Orthod 1965;35:200-17.

2. Haas AJ. Rapid expansion of the maxillary dental arch and nasal cavity by opening the mid-palatal suture. Angle Orthod 1961;31:73-90.

3. Liu S, Xu T, Zou W. Effects of rapid maxillary expansion on the midpalatal suture: a systematic review. Eur J Orthod 2015;37:651-5.

4. Camps-Pereperez I, Guijarro-Martinez R, Peiro-Guijarro MA, Hernandez-Alfaro F. The value of cone beam computed tomography imaging in surgically assisted rapid palatal expansion: a systematic review of the literature. Int J Oral Maxillofac Surg 2017;46:827-38.

5. Chrcanovic BR, Custodio AL. Orthodontic or surgically assisted rapid maxillary expansion. Oral Maxillofac Surg 2009;13:123-37.

6. Suri L, Taneja P. Surgically assisted rapid palatal expansion: a literature review. Am J Orthod Dentofacial Orthop 2008;133:290-302.

7. Lagravere MO, Major PW, Flores-Mir C. Long-term skeletal changes with rapid maxillary expansion: a systematic review. Angle Orthod 2005;75:1046-52.

8. Grunheid T, Larson CE, Larson BE. Midpalatal suture density ratio: 
A novel predictor of skeletal response to rapid maxillary expansion. Am J Orthod Dentofacial Orthop 2017;151:267-76.

9. Angelieri F, Cevidanes LH, Franchi L, Goncalves JR, Benavides E, McNamara JA, Jr. Midpalatal suture maturation: classification method for individual assessment before rapid maxillary expansion. Am J Orthod Dentofacial Orthop 2013;144:759-69.

10. Angelieri F, Franchi L, Cevidanes LH, McNamara JA, Jr. Diagnostic performance of skeletal maturity for the assessment of midpalatal suture maturation. Am J Orthod Dentofacial Orthop 2015;148:1010-6.

11. Tonello DL, Ladewig VM, Guedes FP, Ferreira Conti AC, AlmeidaPedrin RR, Capelozza-Filho L. Midpalatal suture maturation in 11- to 15-year-olds: A cone-beam computed tomographic study. Am J Orthod Dentofacial Orthop 2017;152:42-8.

12. Baccetti T, Franchi L, McNamara JA. The Cervical Vertebral Maturation (CVM) Method for the Assessment of Optimal Treatment Timing in Dentofacial Orthopedics. Semin Orthod 2005;11:119-29.

13. Landis JR, Koch GG. The measurement of observer agreement for categorical data. Biometrics 1977;33:159-74.

14. Baydas B, Yavuz I, Uslu H, Dagsuyu IM, Ceylan I. Nonsurgical rapid maxillary expansion effects on craniofacial structures in young adult females. A bone scintigraphy study. Angle Orthod 2006;76:759-67.

15. Davidovitch M, Efstathiou S, Sarne O, Vardimon AD. Skeletal and dental response to rapid maxillary expansion with 2- versus 4-band appliances. Am J Orthod Dentofacial Orthop 2005;127:483-92.

16. Korbmacher $\mathrm{H}$, Schilling A, Puschel K, Amling M, Kahl-Nieke B. Age-dependent three-dimensional microcomputed tomography analysis of the human midpalatal suture. J Orofac Orthop 2007;68:364-76.

17. Knaup B, Yildizhan F, Wehrbein H. Age-related changes in the midpalatal suture. A histomorphometric study. J Orofac Orthop 2004;65:467-74.

18. Flores-Mir C, Burgess CA, Champney M, Jensen RJ, Pitcher MR, Major PW. Correlation of skeletal maturation stages determined by cervical vertebrae and hand-wrist evaluations. Angle Orthod 2006;76:1-5.

19. Fishman LS. Radiographic evaluation of skeletal maturation. A clinically oriented method based on hand-wrist films. Angle Orthod 1982;52:88-112.

20. Gandini P, Mancini M, Andreani F. A comparison of hand-wrist bone and cervical vertebral analyses in measuring skeletal maturation. Angle Orthod 2006;76:984-9.

21. Litsas G, Ari-Demirkaya A. Growth indicators in orthodontic patients. Part 1: comparison of cervical vertebral maturation and hand-wrist skeletal maturation. Eur J Paediatr Dent 2010;11:171-5.

22. Wehrbein $\mathrm{H}$, Yildizhan $\mathrm{F}$. The mid-palatal suture in young adults. A radiological-histological investigation. Eur J Orthod 2001;23:105-14.

23. Angelieri F, Franchi L, Cevidanes LH, Gonçalves JR, Nieri M, Wolford LM, et al. Cone beam computed tomography evaluation of midpalatal suture maturation in adults. Int $\mathrm{J}$ Oral Maxillofac Surg 2017;46:1557-61

24. Haghanifar S, Mahmoudi S, Foroughi R, Mir AP, Mesgarani A, Bijani A. Assessment of midpalatal suture ossification using cone-beam computed tomography. Electron Physician 2017;9:4035-41.

25. Timms DJ, Vero D. The relationship of rapid maxillary expansion to surgery with special reference to midpalatal synostosis. Br J Oral Surg 1981;19:180-96.
26. Chaconas SJ, Caputo AA. Observation of Orthopedic Force Distribution Produced by Maxillary Orthodontic Appliances. Am J Orthod Dentofacial Orthop 1982;82:492-501.

\section{Midpalatal sutur maturasyonunun yaş ve servikal vertebral maturasyonla ilişkisi: radyografik inceleme}

\section{ÖZET}

AmAç: Bu çalışmanın amacı 15 yaş ve üstündeki bireylerde midpalatal sutur maturasyon aşamalarını değerlendirmek ve bu aşamaların yaş ve servikal vertebral maturasyonla ilişkisini belirlemektir.

GeReç Ve Yöntem: 50 bireyin (29 kadın, 21 erkek; ortalama yaş: $19.79 \pm 4.09$ yıl) konik ışınlı bilgisayarlı tomografi (KIBT) görüntüleri incelendi. Gömülü kanin değerlendirmesi veya ortognatik cerrahi planlaması için alınmış iyi kalitede KIBT görüntüleri olan 15-30 yaş arasındaki bireyler çalışmaya dahil edildi. Midpalatal sutur ve servikal vertebral maturasyon aşamalarının belirlenmesi için KIBT görüntüleri iki farklı zamanda değerlendirildi. Midpalatal sutur maturasyon aşamaları, daha önceden doğrulanmış bir yöntem ile, aksiyel kesitler değerlendirilerek A, B, C, D veya E olarak sınıflandırıldı. Servikal vertebral maturasyon aşamaları ise KIBT görüntülerinin sagital kesitlerinden belirlendi. Gözlemci içi güvenilirlik Kappa testi ile değerlendirildi. Midpalatal sutur maturasyonu ile kronolojik yaș ve servikal vertebral maturasyon arasındaki korelasyon Spearman'ın sıralama korelasyon analizi ile değerlendirildi.

BULGULAR: Gözlemci içi uyumu belirten Kappa katsayıları, midpalatal sutur ve servikal vertabral maturasyon için sırasıyla 0.837 ve 0.865 'ti. Kronolojik yaş ve midpalatal sutur maturasyonu arasında korelasyon önemli bulunmadı $(r=0.212, p=0.139)$. Aynı şekilde, servikal vertebral ve midpalatal sutur maturasyon aşamaları arasında da korelasyon önemli bulunmadı $(r=0.030, p=0.839)$.

SonUç: Küçük örneklem çapında gerçekleştirilmiş bu çalışmanın sınırları dahilinde ne servikal vertebral maturasyon aşaması ne de kronolojik yaş, 15 yaş ve 30 yaş arasındaki bireylerde midpalatal sutur maturasyon aşamasının belirlenmesi için uygun bir araç olarak bulunmadı.

Anahtar Kelimeler: Büyüme ve gelişim; konik ışınlı bilgisayarlı tomografi; ortodonti 